\title{
What Makes for Good Collaboration and Communication in Maternity Care? A Scoping Study
}

Citation for published version (APA):

van Helmond, L., Korstjens, I., Mesman, J., Nieuwenhuijze, M., Horstman, K., Scheepers, H., Spaanderman, M., Keulen, J., \& de Vries, R. (2015). What Makes for Good Collaboration and Communication in Maternity Care? A Scoping Study. International Journal of Childbirth, 5(4), 210-223. https://doi.org/10.1891/2156-5287.5.4.210

Document status and date:

Published: 01/01/2015

DOI:

10.1891/2156-5287.5.4.210

Document Version:

Publisher's PDF, also known as Version of record

Document license:

Taverne

Please check the document version of this publication:

- A submitted manuscript is the version of the article upon submission and before peer-review. There can be important differences between the submitted version and the official published version of record.

People interested in the research are advised to contact the author for the final version of the publication, or visit the DOI to the publisher's website.

- The final author version and the galley proof are versions of the publication after peer review.

- The final published version features the final layout of the paper including the volume, issue and page numbers.

Link to publication

\footnotetext{
General rights rights.

- You may freely distribute the URL identifying the publication in the public portal. please follow below link for the End User Agreement:

www.umlib.nl/taverne-license

Take down policy

If you believe that this document breaches copyright please contact us at:

repository@maastrichtuniversity.nl

providing details and we will investigate your claim.
}

Copyright and moral rights for the publications made accessible in the public portal are retained by the authors and/or other copyright owners and it is a condition of accessing publications that users recognise and abide by the legal requirements associated with these

- Users may download and print one copy of any publication from the public portal for the purpose of private study or research.

- You may not further distribute the material or use it for any profit-making activity or commercial gain

If the publication is distributed under the terms of Article $25 \mathrm{fa}$ of the Dutch Copyright Act, indicated by the "Taverne" license above, 


\title{
What Makes for Good Collaboration and Communication in Maternity Care? A Scoping Study
}

\author{
Isabel van Helmond, Irene Korstjens, Jessica Mesman, \\ Marianne Nieuwenhuijze, Klasien Horstman, Hubertina Scheepers, \\ Marc Spaanderman, Judit Keulen, and Raymond de Vries
}

BACKGROUND: Good communication and collaboration are critical to safe care for mothers and babies.

OBJECTIVE: To identify factors associated with good collaboration and communication among maternity care professionals and between both professionals and parents.

METHOD: Scoping study. We searched PubMed and Web of Science for peer reviewed, quantitative and qualitative, original, primary research in Western societies on communication and collaboration in maternity care among professionals (Search 1) and between professionals and parents (Search 2).

FINDINGS: The 40 studies (14 in Search 1; 26 in Search 2) that met our selection criteria highlighted several factors associated with good communication and collaboration. We grouped these factors into 6 categories: Expertise, Partnership, Context, Attitude, Trust, and Communication style. Studies of communication and collaboration among professionals foregrounded work-related aspects, whereas studies examining collaboration between professionals and parents paid more attention to interpersonal aspects. Before 2012, few studies covered positive aspects of communication and collaboration. We also found an underrepresentation of parents in study populations.

CONCLUSION: Our study is part of a growing trend of identifying the positive aspects of communication and collaboration in maternity care. As the study of collaboration in practice continues, researchers need to be sure to involve all stakeholders, including parents.

KEYWORDS: communication; collaboration; midwifery; maternity care; obstetrics; parents

\section{INTRODUCTION}

Problems with communication and collaboration among perinatal caregivers threaten the quality and safety of care given to mothers and babies (Joint Commission on Accreditation of Healthcare Organizations, 2004; Simpson \& Knox, 2003). Concern with perinatal mortality in the Netherlands, led policymakers there to recommend that maternity caregivers pay special attention to the central role of mother and child, empowerment of clients, and better collaboration between all maternity caregivers (Van der Velden, 2009). Earlier reviews of maternity care work focused on tools to measure collaboration (Downe, Finlayson, \& Fleming, 2010) and on historic developments in collaboration in the United States (Avery, Montgomery, \& Brandl-Salutz, 2012; King, Laros, \& Parer, 2012). All three of these reviews emphasized the need for better interprofessional collaboration in maternity care to provide patient-centered care over the course of childbearing.

Efforts to maintain and improve the quality of communication and collaboration in maternity care must begin with an exploration of what is known about the factors that are associated with good working 
relationships there. In safety and quality research, most studies begin from the premise that we can improve our practices by identifying and eliminating causes of errors, rather than examining and learning from what is going well (Mesman, 2008). We take a different approach. In our exploration of the research, we focused on studies examining the factors associated with good communication and collaboration as they occur in working routines in maternity care practice. Although we can learn from failures, it is equally important to identify and build on existing-but often overlooked or forgotten-collaborative competencies in care practice. This latter approachknown as exnovation (Iedema, Mesman, \& Carroll, 2013; Mesman, 2008; Mesman, 2011)-pays attention to the mundane, implicit routines of care, the invisible but necessary aspects of care work that promote quality. The aim of exnovation is to uncover and use the already available competencies of care providers to improve practices. An important feature of this approach is that it demands consideration of the fact that different parties in maternity care - that is, midwives, obstetricians, general practitioners, nurses, researchers, pregnant women, and their partners-have their own versions of "best" care (De Vries, Nieuwenhuijze, \& van Crimpen, 2011).

The study presented here was done in preparation for our ethnographic study of the nature of good collaboration and communication in maternity care as carried out in midwifery practices and obstetric wards. To guide our work in the field, we did a "scoping study" that allowed us to identify appropriate "sensitizing concepts" (Bowen, 2006). This technique provides us with the possibility to map the understandings of good collaboration and communication already available in the literature (Anderson, Allen, Peckham, \& Goodwin, 2008; Arksey \& O'Malley, 2005; Armstrong, Hall, Doyle, \& Waters, 2011; Davis, Drey, \& Gould, 2009). The advantage of a scoping study over a systematic review is that it allows for the inclusion of different study designs and a broad set of parameters. In addition, a scoping study is iterative and as such allows for adjustments and repeating steps. Like systematic reviews, scoping studies require methodological rigor. Given our focus on exnovation, our scoping study breaks new ground, providing a positive starting point for research for improving and maintaining quality of communication and collaboration in maternity care.

\section{METHOD}

In our scoping study, we used systematic strategies for searching, selection, and data extraction from the literature and a qualitative analysis to find factors associated with good communication and collaboration in maternity care. To ensure the methodological rigor of our scoping study, we used the framework as suggested by Arksey and O'Malley (2005) and structured our research in five stages: (a) identifying the research question; (b) identifying relevant studies; (c) study selection; (d) charting the data; (e) collating, summarizing, and reporting the results.

\section{Identifying the Research Question}

The purpose of our larger research project is the identification of the aspects of good collaboration and communication. This objective motivated us to identify and map already available knowledge and experience as described in the literature. Therefore, our research question was, "What factors are associated with good collaboration and communication as mentioned in literature about maternity care?"

\section{Identifying Relevant Studies}

To allow for differences in understanding, we did not begin with fixed definitions of "collaboration" and "communication." This prevented exclusion of studies using definitions that would not match ours. For the same reasons, we did not define at the outset "positive" and "desired" aspects of communication and collaboration. Because ours was an exploratory study, we restricted our search to articles in PubMed and Web of Science (WoS) up until April 2014 (Table 1). Despite this limitation, our first search found more than half a million articles on collaboration and communication. To eliminate the large number of irrelevant articles, we further restricted our search to maternity care and added Major MEsH terms (PubMed) and Topics (WoS) related to maternity care. Search 1 focused on interprofessional communication and collaboration among maternity care professionals. Search 2 aimed at communication and collaboration between maternity care professionals and parents. We performed two separate searches to identify possible differences in factors associated with good communication and collaboration among professionals and between professionals and parents. However, in both searches, the Major Mesh Terms and Topics did not restrict inclusion of one of the groups, professionals, and parents. Therefore, all included studies in our scoping review had the potential to include both maternity care professionals and parents. 
TABLE 1 Included Studies From Searches 1 and 2 in PubMed and Web of Science $(n=40)$

Search 1: Interdisciplinary communication and collaboration among maternity care professionals PubMed WoS

Communication OR collaboration $216.517 \quad 370.637$ Gynecolog OR midwif OR obstetria 884 1.721 Interdisciplinary OR interprofessional 112 101 OR crew resource management OR teamwork ${ }^{b}$

Included 7 7

Search 2: Communication and collaboration between maternity care professionals and parents PubMed WoS

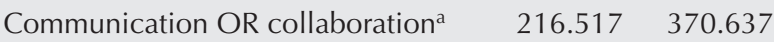

Pregnancy OR mothers OR parents ${ }^{\mathrm{a}} \quad 2905 \quad 12.886$

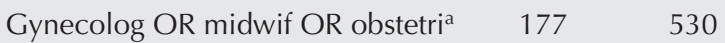

Included

$8 \quad 18$

${ }^{a}$ Major MeSH terms in PubMed, topics in WoS.

${ }^{b}$ All field terms in PubMed, topics in WoS. Included studies after removed duplicates and excluded studies not fulfilling selection criteria.

\section{Study Selection}

To further refine and focus our search, we developed inclusion and exclusion criteria. We decided to include peer-reviewed quantitative and qualitative, original, primary research in maternity care, and applied no limits for language or type of research population (i.e., socioeconomic aspects, ethnicity, and gender). To provide reasonably consistent and comparable health care structures and cultural contexts, we included studies from Western high-resource societies in North America, Oceania, and North-Western Europe and excluded studies from low-resource countries and countries with a non-Western culture. We included publications on everyday maternity care populations that might vary from healthy to high-risk pregnancy and childbirth and excluded publications which particularly focused on specific patient populations in maternity care dealing with defined issues such as rare (medical) conditions. We also excluded secondary research and publications on communication and collaboration in health care education. After removal of duplicate publications, the first three authors $(\mathrm{IvH}, \mathrm{IK}$, $\mathrm{JM}$ ) independently assessed the publications derived from the databases for eligibility (title, keywords, abstract, and full text) excluding all publications that did not meet our selection criteria. In subsequent rounds, they discussed their findings until consensus was reached on the final inclusion of 40 studies for review (Search 1: $n=14$; Search 2: $n=26$ ).

\section{Charting the Data}

To organize our material, we summarized the data from the primary studies being reviewed by charting the relevant information into different tables. The first author ( $\mathrm{IvH})$ extracted the data, whereas the second and third authors (IK, JM) performed duplicate extractions from random samples.

Tables 2 and 3 display the characteristics of the articles found in Search 1 and Search 2: first author and year of publication, objective of the study, country, population, study design, method, and involvement of participants. In addition, we created a file to display the factors associated with good communication and collaboration as reported in the included studies (see Appendix).

\section{Collating, Summarizing, and Reporting the Results}

In this last step of the scoping study, we extracted and analyzed the data and reported the results using guidelines for qualitative inductive content analysis (Elo \& Kyngäs, 2008). This type of analysis aims "to attain a condensed and broad description of the phenomenon and the outcome is categories describing the phenomenon" (Elo \& Kyngäs, 2008, p 108). The first step was to extract from the "Results" sections of the publications all fragments in which factors associated with good communication and collaboration were mentioned. The Appendix presents all the factors mentioned in these fragments. Next, in an iterative process of open coding, creating categories, and abstraction, the second and third authors (IK, JM) independently grouped the factors into main categories and categories (Table 4). Content validation requires the use of dialogue among coresearchers to agree upon the way in which the data are labeled (Elo \& Kyngäs, 2008). Therefore, in subsequent rounds, the first three authors (IvH, IK, JM) compared and discussed the extracted and categorized data until consensus was reached about the aspects and (main) categories under which they should be filed. Last, all authors revisited and discussed these main categories, which can be seen as our sensitizing concepts for our future fieldwork (Bowen, 2006).

\section{RESULTS}

\section{Characteristics of the Studies}

Tables 2 and 3 show the characteristics of the included studies for interprofessional communication and 
TABLE 2 Characteristics of the Included Studies From Search 1: Interdisciplinary Communication and Collaboration Among Maternity Care

Professionals $(n=14)$

\begin{tabular}{|c|c|c|c|c|c|c|c|}
\hline $\begin{array}{l}\text { FIRST AUTHOR, } \\
\text { YEAR }\end{array}$ & OBJECTIVE OR RESEARCH QUESTION & COUNTRY & $\begin{array}{l}\text { POPULATION } \\
(N)\end{array}$ & $\begin{array}{c}\text { TYPE } \\
\text { PARTICIPANTS }\end{array}$ & DESIGN & METHOD & $\begin{array}{l}\text { INVOLVEMENT } \\
\text { PARTICIPANT(S) }\end{array}$ \\
\hline Bahl, 2010 & $\begin{array}{l}\text { To identify the nontechnical skills involved in conducting an } \\
\text { operative vaginal delivery: cognitive, social, interactive com- } \\
\text { munication skills. }\end{array}$ & United Kingdom & 18 & $\mathrm{C}$ & $\mathrm{L}$ & Mix & Yes \\
\hline Berridge, 2010 & $\begin{array}{l}\text { To explore the nature of intraprofessional and interprofessional } \\
\text { communication on delivery suites, with a particular focus on } \\
\text { patient safety. }\end{array}$ & United Kingdom & U & $\mathrm{C}$ & $\mathrm{L}$ & Mix & Yes \\
\hline Bristowe, 2012 & $\begin{array}{l}\text { To investigate health care professionals' beliefs about effective } \\
\text { teamwork in medical emergencies based on their experiences. }\end{array}$ & United Kingdom & 28 & C & $\mathrm{L}$ & $\begin{array}{l}\text { Focus } \\
\text { groups }\end{array}$ & Yes \\
\hline de Veer, 1996 & $\begin{array}{l}\text { To determine the feasibility of cooperation within maternity and } \\
\text { obstetric care between midwives, general practitioners, (GPs) } \\
\text { and obstetricians. }\end{array}$ & Netherlands & 175 & $\mathrm{CP}$ & $\mathrm{T}$ & Mix & Yes \\
\hline Kennedy, 2008 & $\begin{array}{l}\text { To explore the practice of midwifery within a busy urban tertiary } \\
\text { hospital birth setting and to present findings on the relationships } \\
\text { between nurses and midwives in providing maternity care. }\end{array}$ & United States & 30 & $\mathrm{CP}$ & $\mathrm{L}$ & Mix & Yes \\
\hline Lyndon, 2014 & $\begin{array}{l}\text { To explore clinician perspectives on whether they experi- } \\
\text { ence difficulty resolving patient-related concerns or observe } \\
\text { problems with the performance or behavior of colleagues } \\
\text { involved in intrapartum care. }\end{array}$ & United States & 1,932 & $\mathrm{C}$ & $\mathrm{L}$ & $\begin{array}{l}\text { E-mail } \\
\text { survey }\end{array}$ & No \\
\hline Mahera, 2002 & $\begin{array}{l}\text { To examine the role of midwives in the development of birth } \\
\text { narratives. }\end{array}$ & Australia & U & Mi & $\mathrm{L}$ & Interviews & $U$ \\
\hline Murray-Davis, 2011 & $\begin{array}{l}\text { To describe the views of midwives and educators regarding inter- } \\
\text { professional working and learning within midwifery practice. }\end{array}$ & United Kingdom & 39 & Mi & $\mathrm{L}$ & Mix & Yes \\
\hline Nielsen, 2012 & $\begin{array}{l}\text { To outline the structure and processes for establishing a col- } \\
\text { laborative midwife physician practice in a military academic } \\
\text { medical center. }\end{array}$ & United States & U & $\mathrm{CP}$ & U & U & Yes \\
\hline Pecci, 2012 & $\begin{array}{l}\text { To describe the design and implementation of a collaborative } \\
\text { model of intrapartum care that involves obstetricians, mid- } \\
\text { wives, and family physicians. }\end{array}$ & United States & U & $\mathrm{CP}$ & U & U & Yes \\
\hline Reiger, 2009 & $\begin{array}{l}\text { To explore the attitudes of midwives, doctors, and managers in } \\
\text { relation to collaborative maternity practice. }\end{array}$ & Australia & 167 & C & $\mathrm{L}$ & Mix & Yes \\
\hline Simpson, 2006 & $\begin{array}{l}\text { To describe communication between expert labor nurses and } \\
\text { their physician colleagues during labor within the context of the } \\
\text { nurse-managed labor practice model in community hospitals } \\
\text { and its relationship to teamwork and perinatal patient safety. }\end{array}$ & United States & 92 & $\mathrm{C}$ & $\mathrm{L}$ & Mix & No \\
\hline Simpson, 2009 & $\begin{array}{l}\text { To describe how nurses would respond in common clinical } \\
\text { situations involving disagreement with physician colleagues } \\
\text { during labor and birth. }\end{array}$ & United States & 133 & $N$ & $\mathrm{~T}$ & Mix & Yes \\
\hline Van Kelst, 2013 & To explore midwives' views on ideal and actual maternity care. & Belgium & 9 & Mi & $\mathrm{L}$ & Interviews & No \\
\hline
\end{tabular}

Note. $\mathrm{C}=$ combinations of professionals; $\mathrm{L}=$ qualitative; $\mathrm{U}=$ unspecified; $\mathrm{CP}=$ combinations of professionals and parents; $\mathrm{T}=$ quantitative; $\mathrm{Mi}=$ midwives; $\mathrm{N}=($ obstetric $)$ nurses. 
TABLE 3 Characteristics of the Included Studies From Search 2: Communication and Collaboration Between Maternity Care Professionals and

Parents $(n=26)$

\begin{tabular}{|c|c|c|c|c|c|c|c|}
\hline $\begin{array}{l}\text { FIRST AUTHOR, } \\
\text { YEAR }\end{array}$ & OBJECTIVE OR RESEARCH QUESTION & COUNTRY & $\begin{array}{l}\text { POPULATION } \\
(N)\end{array}$ & $\begin{array}{c}\text { TYPE } \\
\text { PARTICIPANTS }\end{array}$ & DESIGN & METHOD & $\begin{array}{l}\text { INVOLVEMENT } \\
\text { PARTICIPANT(S) }\end{array}$ \\
\hline $\begin{array}{c}\text { Alkazaleh, } \\
2004\end{array}$ & $\begin{array}{l}\text { To find out from women who had received bad news as a result of } \\
\text { a pregnancy scan, the relative importance they placed on various } \\
\text { issues, including caregiver behavior, when the news was given: } \\
\text { varying from serious to soft markers/obstetric complications. }\end{array}$ & Canada & 76 & Mo & $\mathrm{T}$ & Survey & Yes \\
\hline Beake, 2013 & $\begin{array}{l}\text { To evaluate caseload midwifery in a relatively deprived and } \\
\text { ethnically diverse inner-city area. }\end{array}$ & United Kingdom & 24 & Mo & L & $\begin{array}{l}\text { Semi-structured } \\
\text { interviews }\end{array}$ & $U$ \\
\hline Borders, 2013 & $\begin{array}{l}\text { To describe how nurse-midwives verbally support nulliparous } \\
\text { women during second-stage labor and document specific de- } \\
\text { tails of each second stage. }\end{array}$ & United States & 23 & $\mathrm{CP}$ & L & Mix & Yes \\
\hline Brown, 2005 & $\begin{array}{l}\text { To investigate the views and experiences of postnatal hospital } \\
\text { care of a representative sample of Victorian women who gave } \\
\text { birth in Victoria, Australia, in } 1999 .\end{array}$ & Australia & 1,358 & Mo & $\mathrm{T}$ & Survey & $U$ \\
\hline Browne, 2014 & $\begin{array}{l}\text { To identify strategies midwives use to amplify women's own resources } \\
\text { and capacities, with the aim of reducing antenatal anxiety. }\end{array}$ & Australia & 14 & Mi & L & Focus Groups & No \\
\hline Burns, 2013 & $\begin{array}{l}\text { To describe the language and practices used by midwives when } \\
\text { supporting breastfeeding women during the first week after birth. }\end{array}$ & Australia & $U$ & $\mathrm{CP}$ & L & Mix & $U$ \\
\hline Bylund, 2005 & $\begin{array}{l}\text { To examine clinician-patient communication and decision making } \\
\text { through the quantitative analysis of women's online birth stories. }\end{array}$ & United States & 551 & Mo & $\mathrm{T}$ & $\begin{array}{l}\text { Online birth } \\
\text { stories }\end{array}$ & $U$ \\
\hline Eri, 2010 & $\begin{array}{l}\text { To explore Norwegian nulliparous women's experiences of com- } \\
\text { munication and contact with midwives at the labor ward in the } \\
\text { early phase of labor. }\end{array}$ & Norway & 17 & Mo & L & Mix & $U$ \\
\hline Eri, 2011 & $\begin{array}{l}\text { To explore the priorities and strategies midwives in a labor ward } \\
\text { use in their communication with primiparous women who seek } \\
\text { contact in the early phase of labor. }\end{array}$ & Norway & 18 & Mi & L & Focus groups & U \\
\hline Forti, 2013 & $\begin{array}{l}\text { Which communication modalities are used, and most frequently } \\
\text { by MGP midwives and clients? }\end{array}$ & Australia & $U$ & $\mathrm{CP}$ & $\mathrm{T}$ & Mix & Yes \\
\hline Fraser, 1999 & $\begin{array}{l}\text { To enable the views and experiences of local women to influence } \\
\text { curriculum development in a large university in England. }\end{array}$ & United Kingdom & 41 & Mo & L & Interviews & $U$ \\
\hline Goodall, 2009 & $\begin{array}{l}\text { To explore mothers' perceptions of the influences of health } \\
\text { professionals (GPs, midwives, and consultants) on decisions as } \\
\text { to mode of delivery of second children, following a previous } \\
\text { cesarean section. }\end{array}$ & United Kingdom & 10 & Mo & L & Interviews & $U$ \\
\hline Hunter, 2006 & $\begin{array}{l}\text { To explore the emotion work experiences of community-based } \\
\text { midwives, focusing on their relationships with clients. }\end{array}$ & United Kingdom & 19 & Mi & L & Mix & Yes \\
\hline Jonkers, 2011 & $\begin{array}{l}\text { To investigate ethnicity-related factors contributing to substandard } \\
\text { maternity care and the effects on severe maternal morbidity } \\
\text { among immigrant women in the Netherlands. }\end{array}$ & Netherlands & 54 & $\mathrm{CP}$ & L & Interviews & $U$ \\
\hline
\end{tabular}




\begin{tabular}{|c|c|c|c|c|c|c|c|}
\hline Lerman, 2007 & $\begin{array}{l}\text { To examine the predictive effects of patients' emotional distress } \\
\text { and their relationships with their health care providers on satis- } \\
\text { faction with obstetric services in high-risk pregnancies. }\end{array}$ & United States & $U$ & Mo & $\mathrm{T}$ & Survey & $U$ \\
\hline Matthias, 2007 & $\begin{array}{l}\text { To understand the mother-midwife relationship in a case study to } \\
\text { examine one woman's struggles with the uncertainties she faces } \\
\text { during her pregnancy. }\end{array}$ & United States & 2 & $\mathrm{CP}$ & L & Mix & Yes \\
\hline Matthias, 2009 & $\begin{array}{l}\text { To explore the struggles that pregnant mothers face and the role } \\
\text { that their practitioners play in these dilemmas. }\end{array}$ & United States & 8 & $\mathrm{CP}$ & L & Mix & $U$ \\
\hline McKay, 1990 & $\begin{array}{l}\text { To discuss "obstetrics by ear" during second stage labor-that } \\
\text { is, the auditory perceptual skills caregivers use in response to } \\
\text { parturients' behavioral cues. }\end{array}$ & United States & 26 & $\mathrm{CP}$ & $\mathrm{L}$ & Mix & Yes \\
\hline Munro, 2013 & $\begin{array}{l}\text { To explore the barriers to and facilitators of interprofessional } \\
\text { models of maternity care between physicians, nurses, and mid- } \\
\text { wives in rural British Columbia, Canada, and the changes that } \\
\text { need to occur to facilitate such models. }\end{array}$ & Canada & $U$ & $\mathrm{CP}$ & L & Mix & Yes \\
\hline Persson, 2011 & $\begin{array}{l}\text { To describe factors which influence mothers' sense of security } \\
\text { during the first postnatal week. }\end{array}$ & Sweden & 11 & Mo & $\mathrm{L}$ & Interviews & U \\
\hline Risa, 2011 & $\begin{array}{l}\text { To explore the verbal communication patterns in antenatal con- } \\
\text { sultations between pregnant women with diabetes and their } \\
\text { midwives. }\end{array}$ & Norway & 17 & $\mathrm{CP}$ & $\mathrm{L}$ & $\begin{array}{l}\text { Audiotaped } \\
\text { consultations }\end{array}$ & U \\
\hline $\begin{array}{l}\text { Schölmerich, } \\
2014\end{array}$ & $\begin{array}{l}\text { To examine coordination challenges that might present a barrier } \\
\text { to delivering optimal care }\end{array}$ & Netherlands & 40 & $\mathrm{C}$ & $\mathrm{L}$ & Mix & No \\
\hline Siassakos, 2011 & $\begin{array}{l}\text { To determine the range of communication practices between staff } \\
\text { and patients during a simulated acute event, an eclamptic seizure. }\end{array}$ & United Kingdom & $U$ & $\mathrm{C}$ & $\mathrm{T}$ & $\begin{array}{l}\text { Simulated } \\
\text { emergency }\end{array}$ & $U$ \\
\hline Sinivaara, 2004 & $\begin{array}{l}\text { To describe delivery ward staff opinions about the exercise of } \\
\text { power over women in communication, focused on "power } \\
\text { over," the ability or capacity to influence the behavior and deci- } \\
\text { sions of others to obey or conform. }\end{array}$ & Finland & 155 & $\mathrm{C}$ & $\mathrm{T}$ & Survey & No \\
\hline Wheatley, 2008 & $\begin{array}{l}\text { To examine what women's pregnancy narratives tell us about the } \\
\text { nature and quality of their experiences with prenatal care. }\end{array}$ & United States & 87 & Mo & $\mathrm{L}$ & Mix & $U$ \\
\hline Williams, 2010 & $\begin{array}{l}\text { To evaluate mothers' satisfaction with a caseload-midwifery } \\
\text { scheme and whether this varied according to the extent of } \\
\text { continuity of care provided. }\end{array}$ & Australia & $U$ & Mo & $\mathrm{T}$ & Mix & $U$ \\
\hline
\end{tabular}

Note. $\mathrm{Mo}=$ mothers $; \mathrm{T}=$ quantitative $\mathrm{L}=$ qualitative; $\mathrm{U}=$ unspecified $; \mathrm{CP}=$ combinations of professionals and parents; $\mathrm{Mi}=$ midwives $\mathrm{C}=$ combinations of professionals; $\mathrm{MGP}=$ midwifery group practice. 
TABLE 4 Main Categories and Categories Associated With "Good" Communication and Collaboration Among Maternity Care Professionals and Between Maternity Care Professionals and Parents in Searches 1 and 2

\section{AMONG MATERNITY CARE PROFESSIONALS}

\section{BETWEEN MATERNITY CARE PROFESSIONALS AND PARENTS}

Explicit

Knowledgeable

Clinical, resources, understanding nature of emergency

Awareness

Of clinical situation, team and patient, recognition of emergency situation

Reliable

Able, competent, up to date, no unnecessary interventions

Time

Willingness to invest time

Architecture

Shared spaces, meeting rooms

Organization of work

Formal plans and protocols, effective meetings, distribution of roles and responsibilities, financial, information flow and channels (ICT, regular meetings), multidisciplinary teamwork, education and training, safe staff/patient ratio

Shared knowledge and decision making

Asks my opinion, trusts my judgment

Different but equal

Distribution of workload, involvement, power, and respect; on level of expertise

Respectful

Respects others' commitment, what we do,

Proactive

Anticipation needs, regular familiarization, explaining roles, abilities, and responsibilities in advance (of emergencies)

Reflexive

Ability to reflect on practice, acknowledgement of vulnerability

Implicit

Attitude

Patient focus

Woman-centered, caring, kind, courteous

Collegiality

Respect, accessible, commitment, patient, openness (to other opinions, about own limits), willingness to cooperate

Task orientation

Anticipation, responsive, sharing (info and expertise), commitment to safety culture

Assertiveness

Firm, risk-taking, confident, independent, initiative
Knowledgeable

Good at job, competent, competence instills confidence

Looking for nonverbal cues

Expect, support, and explain women's sounds and help when needed, vigilance

Expertise and experience

Advantage of different professional competences Context

Time

For info sharing, discussions, for partner, to rest Atmosphere

Comfortable, privacy, natural and normal process, practical support, follow-up, safe environment, own environment

Communication channels

Mobile technologies

Partnership

Shared decision making

Choice, time, opportunity to discuss, consent, participation

in own care

Reciprocity

Rapport, affirmation and validation of roles and responsibilities, mutual appreciation, connection over surveillance

Balanced exchange

Sense of control, openness, empowerment

\section{Attentiveness}

Woman-centered, sensitive and responsive to needs, acknowledge partner, affirmative, active listening, (non) explicit info

Empathic

Supportive, empower, patient, understanding

\author{
Nonjudgmental \\ Respect, open, moral sensitivity \\ Calm demeanor \\ Bring peace and quiet
}




\section{TABLE 4 Main Categories and Categories Associated With "Good” Communication and Collaboration Among Maternity Care Professionals and Between Maternity Care Professionals and Parents in Searches 1 and 2 (cont.)}

AMONG MATERNITY CARE PROFESSIONALS
Trust
Others professional ability and expertise, confidence
Open and honest
Open to discussions, open to different viewpoints
Structured and directive
Clear and assertive, firm, focused, logical
Form
Calm, ability to listen, respectful, with dignity, humor
Empathic
Kind, patient-centered

\section{BETWEEN MATERNITY CARE PROFESSIONALS AND PARENTS}

Trust

Trustworthy

Authentic, listen and take seriously, being open and honest, relevant information

Individualized care

Being met as an individual, physical touch, massage, closeness

Continuity of care

Personal relationships, consistency throughout chain

Availability

Someone to turn to

Communication style

Info-sharing

Reporting, advising, consistent, straightforward, clear, adapted to level of understanding, personalized (not just risk)information

Form

Calm, use of small talk, directive, humor, immediate feedback, clear

Normalizing the situation

Explaining and asking questions, challenging negative perceptions, "birth as natural" perspective

Informative

Explanatory; what is and is expected, information about potential complications

Vocabulary

Respectful, nonclinical terms (baby), reframe of language ("possibility" instead of "risk")

Note. ICT $=$ information and communication technology.

collaboration among maternity care professionals (Search $1 ; n=14$ ) and for communication and collaboration between maternity care professionals and parents (Search 2; $n=26$ ).

There are several noteworthy characteristics of these studies. First, all studies, except one from Search 2 (McKay \& Roberts, 1990), were published relatively recently in the years 1995-2014. Second, the studies were performed in many different regions within the Western world: Search 1: Western Europe $(n=6)$, United States $(n=6)$, Australia $(n=2)$; Search 2: Western Europe $(n=7)$, Northern Europe $(n=5)$, United States $(n=7)$, Canada $(n=2)$, or Australia $(n=5$; Table 2 and Table 3; see Country). Third, although all studies had the potential to include maternity care professionals and parents, most studies included only one of these groups. Search 1 resulted in 10 studies with populations consisting of maternity care professionals and 4 studies populations consisting of both professionals and parents (Table 2, see Type Participants). In Search 2, 9 of 26 studies included both professionals and parents in their study population (Table 3, see Type Participants). Fourth, the designs of the studies were predominantly qualitative: Search 1: qualitative $(n=10)$, quantitative $(n=2)$, unspecified $(n=2)$; Search 2: qualitative $(n=18)$, quantitative ( $n=8$; Table 2 and Table 3: see Design). Fifth, only 15 out of 40 publications referred to active involvement in the research projects by participants in the form of feedback, evaluation, member check, input, or research group membership (see Table 2 and 3, see Involvement Participants): 10 studies for Search 1 and 5 studies for Search 2 . These publications are almost equally divided between studies that do and do not include parents in their study population (see Tables 2 and 3, see Type Participants). Last, most striking is that Search 2, devoted to communication and collaboration between professionals and parents, includes only 9 studies out of 26 where both parents and professionals were consulted as part of the study (see Table 3, see Type Participants). An interesting example of this phenomenon is a publication 
(Hunter, 2006) that discusses the theory of reciprocity in relationships between midwives and mothers whereas including only midwives in the study population.

\section{Findings of Factors Associated With Good Communication and Collaboration}

None of the studies in Search 1 and 2 were explicitly aiming for identifying factors associated with good communication and collaboration in practice. Their focus was mainly on (solving) problems and weaknesses in communication and collaboration. We found only six articles (Beake, Acosta, Cooke, \& McCourt, 2013; Borders, Wendland, Haozous, Leeman, \& Rogers, 2013; Browne, O’Brien, Taylor, Bowman, \& Davis, 2014; Nielsen, et al., 2012; Pecci, et al., 2012; Van Kelst, Spitz, Sermeus, \& Thomson 2013) with a predominant focus on positive aspects. Interestingly, some of the positive aspects found were even described in a negative way (see Appendix). For example, one study described an aspect of good communication as, "doesn't yell or scream" (Simpson, James, \& Knox, 2006). Also, most articles $(n=31)$ made no clear distinction between communication and collaboration. Therefore, it was not possible to categorize the positive aspects into aspects of communication on the one side and collaboration on the other. None of the authors explicitly defined "good" communication and/ or collaboration. Only some articles provided (partial) definitions of communication $(n=4$; Borders, et al., 2013; Burns, Fenwick, Sheehan, \& Schmied, 2013; Risa, Lidén, \& Friberg, 2011; Sinivaara, Suominen, Routasalo, \& Hupli, 2004), collaboration ( $n=3$; Munro, Komelsen, \& Grzybowski, 2013; Nielsen, et al., 2012; Wheatley, Kelley, Peacock, \& Delgado, 2008), or both $(n=2$; Schölmerich, et al., 2014; Simpson, et al., 2006).

Our examination of the 40 studies revealed six overlapping and interconnected main categories for the factors associated with good communication and collaboration: Expertise, Partnership, Context, Attitude, Trust, and Communication style (Table 4).

These sensitizing concepts for our fieldwork made us aware of the possibility to distinguish two groups of prerequisites for good communication and collaboration: implicit prerequisites and explicit ones. As such, they offered us new ways of interpreting and organizing our data. The main categories Expertise, Partnership, and Context can be grouped under the heading "explicit" prerequisites of good communication and collaboration. "Explicit" because they are closely linked to "doing things together" and, therefore, often part of a written regulation or topics being discussed. Examples are the distribution of workload among professionals or the requirement that patients provide informed consent. The main categories Attitude, Trust, and Communication style, can be gathered under the heading "implicit" prerequisites of good communication and collaboration, as they assume an implicit form of "being together." Attitude, Trust, and Communication Style comprise more implicit personal characteristics or preferences that can be felt by group(s) or individual(s), for example, respect among colleagues and between professionals and parents.

Closer examination of the categories and their content revealed that there are differences between the findings from the two searches (Table 4). The studies found in Search 1 on interprofessional communication and collaboration had a more practical stance, meaning that they focused more on the actual "doing" (explicit prerequisites) and placed less emphasis on ways of "being" ("implicit" prerequisites) compared to the studies from Search 2. For example, the main category Attitude in Search 1 included the more practical categories Patient focus, Collegiality, Task orientation, and Assertiveness, as ways of doing the job together. In Search 2, the same main category Attitude included the categories Attentiveness, Empathic, Nonjudgmental, and Calm demeanor. These categories can be interpreted as ways of being together emotionally (not physically). This difference can also be noticed when we look at the category Organization of work, which is a clear example of doing the job together; this category is present in Search 1 and absent in Search 2. Considering these findings, one should expect that Search 1 resulted in a less elaborate list of categories regarding Attitude, Trust, and Communication style. This expectation was confirmed (Table 4). Another example is the main category Context containing the categories Architecture (Search 1) and Atmosphere (Search 2). "Architecture," mentioned in two articles (Murray-Davis, Marshall, \& Gordon, 2011; Simpson \& Lyndon, 2009), refers to, for example, the shared space (such as coffee room), whereas "Atmosphere," mentioned in six articles (Borders, et al., 2013; Burns, et al., 2013; Fraser, 1999; Munro, et al., 2013; Persson, Fridlund, Kvist, \& Dykes, 2011; Schölmerich, et al., 2014) focuses on things such as the effect of the built environment on someone's mood, emotions, and overall birth or work experience.

\section{DISCUSSION}

This scoping study provides a thorough overview of the factors associated with good communication and 
collaboration in maternity care. The focus of the 40 included studies is predominantly on problems and solutions; and as these studies hardly define what is good communication and collaboration, they seem to start from the assumption of a common or shared understanding about these concepts. Interestingly, the six studies focusing on positive aspects were all published in 2012 and 2014, indicating that attention for the positive aspects of communication and collaboration is a recent development.

We identified factors associated with good communication and collaboration among maternity care professionals (Search 1) and between maternity care professionals and parents (Search 2). On an aggregated level, both searches resulted in the same main categories which can be divided into "explicit" prerequisites of good communication and collaboration: Expertise, Partnership, Context, and implicit prerequisites: Attitude, Trust, and Communication style. Analysis on a more detailed level (categories) showed differences in perspectives on what factors exactly are important. This suggests that in maternity care, different approaches might be needed for improvement of communication and collaboration among professionals compared to improvement of communication and collaboration between professionals and parents. The categories revealed that research on communication and collaboration between maternity care professionals results predominantly in "explicit" work-related aspects, whereas implicit interpersonal aspects receive less attention. These findings indicate a limited focus of research on interprofessional communication and collaboration. We would like to stress that these studies should also be attentive to the "implicit" prerequisites of good communication and collaboration. Likewise, collaboration between maternity care professionals and parents should consider "explicit" prerequisites, including, for example, the way all stakeholders are influenced by the organization of work.

Most articles ignored parents as partners in communication and collaboration by not including them in the study population. Their underrepresentation and limited involvement in the form of feedback, evaluation, member checking, input, or membership in the research projects indicate the need for more research in maternity care that involves all stakeholders, rather than just gathering information about them from others. Also noteworthy is the increasing attention given to the tangible environment and its influence on communication and collaboration (Architecture and Atmosphere). Environment plays an important role in effective communication and collaboration practices, especially in a time where more and more hospitals are being (partly) refurnished and rebuilt to meet the requirements of, for example, the UNICEF's (revised) Baby-Friendly Hospital Initiative (2009). It is noteworthy that although only eight publications addressed Architecture and Atmosphere, six were published in 2011-2014, implying that these aspects have come to maternity care researchers' attention more recently.

Three reviews (Avery et al., 2012; Downe et al., 2010; King et al., 2012) addressed collaboration in maternity care and seemed to consider communication and collaboration as being overlapping and multilayered concepts. The narrative overview of Downe et al. (2010) described tools designed to measure collaboration and teamwork in the general health care context. They identified contextual components (e.g., clear boundaries, shared responsibilities, cohesion, interdependence, openness, trust, and conflict resolution) and factors of influence (e.g., supportive organizational structure and resources, history of collaboration, and positive attitude). Avery et al. (2012) conducted a qualitative analysis of 12 out of 60 articles that were submitted after a competitive call for collaborative articles from the American College of Obstetricians and Gynecologists and the American College of Nurse-Midwives. The authors distil five main themes for successful and sustainable models of midwife and obstetrician collaborative practice: impetus for collaboration, foundations of collaborative care, commitment to partnership, care integration, and interprofessional education. In their review of the history of collaboration in maternity care in the United States, King et al. (2012) conclude that in the future, interdisciplinary teams will be required to provide seamless access for patients whose health care may change over the course of childbearing. According to them, the success of interdisciplinary teams is dependent on professional competence, interprofessional respect, and a common orientation to the patient. Our scoping study supports the perspective of communication and collaboration as overlapping and multilayered concepts. Moreover, it identifies various aspects within the different intertwined categories of good communication and collaboration found in research in maternity care.

We used the framework of a scoping study as part of preparation for an ethnographic study in maternity care on collaboration and communication. The advantage of a scoping study is its open character, allowing in our case, the inclusion of studies from a range of Western high-resource societies with various study 
designs, and varied levels of analysis. This openness provided us the sensitizing concepts needed as guidance for our fieldwork. Following the scoping study principles, we did not appraise the methodological quality of the studies and, therefore, cannot exclude selection and information bias. A disadvantage of the openness of a scoping study is a lack of clearly defined categories as found in the literature. When defining main categories, we sometimes ran into problems because of overlap between them; for example, Attitude is strongly related to Partnership, Trust, and Communication style. Therefore, the authors engaged in an extensive dialogue to reach consensus and acknowledged that the main categories are interconnected. The importance and interconnectedness of communication and collaboration in maternity care can be illustrated by a study, which did not primarily focus on communication and collaboration (Hall, Tomkinson, \& Klein, 2012). This qualitative study explores care providers' and pregnant women's approaches to the complicated issues of risk in pregnancy and birth. The authors find how risk and integrity can be defined differently and how strategies to minimize risk and maximize integrity were influenced by relationships (e.g., between professionals and women), evidence, and local health care cultures. These influencing factors can be categorized in our (explicit) main categories Partnership, Expertise, and Context, which are strongly connected.

In general, it remains unclear if the factors in the 40 selected publications are mentioned as descriptive or prescriptive, and several factors might be perceived as "basic," such as listening to sounds and spending more time with women. However, it is important to pay attention to the mundane, implicit routines of care, the often overlooked or forgotten but necessary aspects of care work that promote quality (Iedema et al., 2013; Mesman, 2008; Mesman, 2011). So in this scoping review, we are not aiming for theoretical articulations, but for the practical identification of aspects of good communication and collaboration that can be explored in interviews and observations in our fieldwork. This will allow us to develop theory about the interactions between these aspects in everyday maternity care based on our ethnographic work. Therefore, we consider the findings from our scoping study in their own right and, moreover, as point of departure for fieldwork that will allow us to further explore the spectrum of factors occurring in practice.

This study raises awareness about the importance of learning from strengths in maternity care practice, not just weaknesses to strive for better communication and collaboration in maternity care. It makes clear that the study of communication and collaboration in maternity care suffers from (a) a lack of attention for the positive (explicit and implicit) aspects involved in communication and collaboration, (b) underrepresentation of parents in study populations, and (c) insufficient involvement of all stakeholders in the research projects.

Studies of collaboration in other health care domains have shown that good communication and collaboration have a broad scope of characteristics and deserve the attention of researchers (Greenhalgh, 2008; Greenhalgh et al., 2008; Mesman, 2009; Parker, Vermeulen, \& Penders, 2010; Swinglehurst, Greenhalgh, Myall, \& Russell, 2010). These insights have not yet been brought to the field of maternity care as evidenced by the fact that most articles in our scoping study focused solely on (solving) problems in communication and collaboration. Good communication and collaboration involves more than the absence of undesirable features; the realization and preservation of effective communication and collaboration also requires identification and understanding of the elements of positive interactions in the maternity care arena.

To that end, our study identifies the "explicit" prerequisites of good collaboration -Expertise, Partnership, and Context-as well as the "implicit" prerequisitesAttitude, Trust, and Communication style. For maternity care practice and research, our study ties in with recent attention for positive ingredients of communication and collaboration. It draws attention to the importance of "implicit" interpersonal aspects of communication and collaboration among maternity care professionals. Likewise, it underlines the importance of "explicit" work-related aspects in communication and collaboration between professionals and parents. Future ethnographic in-depth research on positive aspects, involving all stakeholders, will provide further insight into the specific nature and dynamics of the interconnected prerequisites of good communication and collaboration in maternity care.

\section{REFERENCES}

Alkazaleh, F., Thomas, F., Grebenyuk, J., Glaude, L., Savage, D., Johannesen, J., . . . Windrim, R. (2004). What women want: Women's preferences of caregiver behavior when prenatal sonography findings are abnormal. Ultrasound in Obstetrics \& Gynecology, 23(1), 56-62. 
Anderson, S., Allen, P., Peckham, S., \& Goodwin, N. (2008). Asking the right questions: Scoping studies in the commissioning of research on the organisation and delivery of health services. Health Research Policy and Systems/ BioMed Central, 6(7).

Arksey, H., \& O’Malley, L. (2005). Scoping studies: Towards a methodological framework. International Journal of Social Research Methodology, 8(1), 19-32.

Armstrong, R., Hall, B. J., Doyle, J., \& Waters, E. (2011). Cochrane update. 'Scoping the scope' of a cochrane review. Journal of Public Health, 33(1), 147-150.

Avery, M. D., Montgomery, O., \& Brandl-Salutz, E. (2012). Essential components of successful collaborative maternity care models: The ACOG-ACNM project. Obstetrics and Gynecology Clinics of North America, 39(3), 423-434.

Bahl, R., Murphy, D. J., \& Strachan, B. (2010). Non-technical skills for obstetricians conducting forceps and vacuum deliveries: Qualitative analysis by interviews and video recordings. European Journal of Obstetrics \& Gynecology and Reproductive Biology, 150(2), 147-151.

Beake, S., Acosta, L., Cooke, P., \& McCourt, C. (2013). Caseload midwifery in a multi-ethnic community: The women's experiences. Midwifery, 29(8), 996-1002.

Berridge, E. J., Mackintosh, N. J., \& Freeth, D. S. (2010). Supporting patient safety: Examining communication within delivery suite teams through contrasting approaches to research observation. Midwifery, 26(5), 512-519.

Borders, N., Wendland, C., Haozous, E., Leeman, L., \& Rogers, R. (2013). Midwives' verbal support of nulliparous women in second-stage labor. Journal of Obstetric, Gynecologic, \& Neonatal Nursing, 42(3), 311-320.

Bowen, G. A. (2006). Grounded theory and sensitizing concepts. International Journal of Qualitative Methods, 5(3), 12-23.

Bristowe, K., Siassakos, D., Hambly, H., Angouri, J., Yelland, A., Draycott, T. J., \& Fox, R. (2012). Teamwork for clinical emergencies: Interprofessional focus group analysis and triangulation with simulation. Qualitative Health Research, 22(10), 1383-1394.

Brown, S. J., Davey, M. A., \& Bruinsma, F. J. (2005). Women's views and experiences of postnatal hospital care in the Victorian Survey of Recent Mothers 2000. Midwifery, 21(2), 109-126.

Browne, J., O’Brien, M., Taylor, J., Bowman, R., \& Davis, D. (2014). 'You've got it within you': The political act of keeping a wellness focus in the antenatal time. Midwifery, 30(4), 420-426.

Burns, E., Fenwick, J., Sheehan, A., \& Schmied, V. (2013). Mining for liquid gold: Midwifery language and practices associated with early breastfeeding support. Maternal \& Child Nutrition, 9(1), 57-73.

Bylund, C. L. (2005). Mothers' involvement in decision making during the birthing process: A quantitative analysis of women's online birth stories. Health Communication, 18(1), 23-39.

Davis, K., Drey, N., \& Gould, D. (2009). What are scoping studies? A review of the nursing literature. International Journal of Nursing Studies, 46(10), 1386-1400.

de Veer, A. J., \& Meijer, W. J. (1996). Obstetric care: Competition or co-operation. Midwifery, 12(1), 4-10.

De Vries, R. G., Nieuwenhuijze, M., \& van Crimpen, R. (2011). The necessity and challenge of international midwifery science. International Journal of Childbirth, 1(1), 61-64.

Downe, S., Finlayson, K., \& Fleming, A. (2010). Creating a collaborative culture in maternity care. Journal of Midwifery \& Women's Health, 55(3), 250-254.

Elo, S., \& Kyngäs, H. (2008). The qualitative content analysis process. Journal of Advanced Nursing, 62(1), 107-115.

Eri, T. S., Blystad, A., Gjengedal, E., \& Blaaka, G. (2010). Negotiating credibility: First-time mothers' experiences of contact with the labour ward before hospitalisation. Midwifery, 26(6), E25-E30.

Eri, T. S., Blystad, A., Gjengedal, E., \& Blaaka, G. (2011). 'Stay home for as long as possible': Midwives' priorities and strategies in communicating with first-time mothers in early labour. Midwifery, 27(6), E286-E292.

Forti, A., Stapleton, H., \& Kildea, S. (2013). Mobile technologies and communication strategies in an urban Midwifery Group Practice setting. An exploratory study. Women and Birth, 26(4), 235-239.

Fraser, D. M. (1999). Women's perceptions of midwifery care: A longitudinal study to shape curriculum development. Birth, 26(2), 99-107.

Goodall, K. E., McVittie, C., \& Magill, M. (2009). Birth choice following primary caesarean section: Mothers' perceptions of the influence of health professionals on decision making. Journal of Reproductive and Infant Psychology, 27(1), 4-14.

Greenhalgh, T. (2008). Role of routines in collaborative work in healthcare organisations. British Medical Journal, 337, a2448.

Greenhalgh, T., Stramer, K., Bratan, T., Byrne, E., Mohammad, Y., \& Russell, J. (2008). Introduction of shared electronic records: Multi-site case study using diffusion of innovation theory. British Medical Journal, 337, a1786.

Hall, W. A., Tomkinson, J., \& Klein, M. C. (2012) Canadian care providers' and pregnant women's approaches to managing birth: Minimizing risk while maximizing integrity. Qualitative Health Research, 22(5), 575-586. 
Hunter, B. (2006). The importance of reciprocity in relationships between community-based midwives and mothers. Midwifery, 22(4), 308-322.

Iedema, R., Mesman, J., \& Carroll, K. (2013). Visualising health care practice improvement: Innovation from within. London, United Kingdom: Radcliffe.

Joint Commission on Accreditation of Healthcare Organizations. (2004). Preventing infant death and injury during delivery. Joint Commission Perspectives, 24(9), 14-15.

Jonkers, M., Richters, A., Zwart, J., Öry, F., \& van Roosmalen, J. (2011). Severe maternal morbidity among immigrant women in the Netherlands: Patients' perspectives. Reproductive Health Matters, 19(37), 144-153.

Kennedy, H. P., \& Lyndon, A. (2008). Tensions and teamwork in nursing and midwifery relationships. Journal of Obstetric Gynecologic, and Neonatal Nursing, 37(4), 426-435.

King, T. L., Laros, R. K., Jr., \& Parer, J. T. (2012). Interprofessional collaborative practice in obstetrics and midwifery. Obstetrics and Gynecology Clinics of North America, 39(3), 411-422.

Lerman, S. F., Shahar, G., Czarkowski, K. A., Kurshan, N., Magriples, U., Mayes, L. C., . . Epperson, C. N. (2007). Predictors of satisfaction with obstetric care in highrisk pregnancy: The importance of patient-provider relationship. Journal of Clinical Psychology in Medical Settings, 14(4), 330-334.

Lyndon, A., Zlatnik, M. G., Maxfield, D. G., Lewis, A., McMillan, C., \& Kennedy, H. P. (2014). Contributions of clinical disconnections and unresolved conflict to failures in intrapartum safety. Journal of Obstetric, Gynecologic, and Neonatal Nursing, 43(1), 2-12.

Mahera, J. M., \& Souter, K. T. (2002). Midwifery work and the making of narrative. Nursing Inquiry, 9(1), 37-42.

Matthias, M. S. (2009). Problematic integration in pregnancy and childbirth: Contrasting approaches to uncertainty and desire in obstetric and midwifery care. Health Communication, 24(1), 60-70.

Matthias, M. S., \& Babrow, A. S. (2007). Problematic integration of uncertainty and desire in pregnancy. Qualitative Health Research, 17(6), 786-798.

McKay, S., \& Roberts, J. (1990). Obstetrics by ear. Maternal and caregiver perceptions of the meaning of maternal sounds during second stage labor. Journal of NurseMidwifery, 35(5), 266-273.

Mesman, J. (2008). Uncertainty in medical innovation: Experienced pioneers in neonatal care. Hampshire, United Kingdom: Palgrave MacMillan.

Mesman, J. (2009). The geography of patient safety: A topical analysis of sterility. Social Science \& Medicine, 69(12), $1705-1712$.
Mesman, J. (2011). A socio-cultural perspective on patient safety. In E. Rowley \& J. Waring (Eds.), A socio-cultural perspective on patient safety (pp. 72-92). Burlington, VT: Ashgate.

Munro, S., Kornelsen, J., \& Grzybowski, S. (2013). Models of maternity care in rural environments: Barriers and attributes of interprofessional collaboration with midwives. Midwifery, 29(6), 646-652.

Murray-Davis, B., Marshall, M., \& Gordon, F. (2011). What do midwives think about interprofessional working and learning? Midwifery, 27(3), 376-381.

Nielsen, P. E., Munroe, M., Foglia, L., Piecek, R. I., Backman, M. P., Cypher, R., \& Smith, D. C. (2012). Collaborative practice model: Madigan army medical center. Obstetrics and Gynecology Clinics of North America, 39(3), 399-410.

Parker, J. N., Vermeulen, N., \& Penders, B. (2010). Collaboration in the new life sciences. Burlington, VT: Ashgate.

Pecci, C. C., Mottl-Santiago, J., Culpepper, L., Heffner, L., McMahan, T., \& Lee-Parritz, A. (2012). The birth of a collaborative model obstetricians, midwives, and family physicians. Obstetrics and Gynecology Clinics of North America, 39(3), 323-334.

Persson, E. K., Fridlund, B., Kvist, L. J., \& Dykes, A. K. (2011). Mothers' sense of security in the first postnatal week: Interview study. Journal of Advanced Nursing, 67(1), 105-116.

Reiger, K. M., \& Lane, K. L. (2009). Working together: Collaboration between midwives and doctors in public hospitals. Australian Health Review, 33(2), 315-324.

Risa, C. F., Lidén, E., \& Friberg, F. (2011). Communication patterns in antenatal diabetes care: An explorative and descriptive study of midwife-led consultations. Journal of Clinical Nursing, 20(13-14), 2053-2063.

Schölmerich, V. L., Posthumus, A. G., Ghorashi, H., Waelput, A. J., Groenewegen, P., \& Denktas, S. (2014). Improving interprofessional coordination in Dutch midwifery and obstetrics: A qualitative study. BMC Pregnancy and Childbirth, 14, 145.

Siassakos, D., Bristowe, K., Hambly, H., Angouri, J., Crofts, J. F., Winter, C., . . . Draycott, T. J. (2011). Team communication with patient actors findings from a multisite simulation study. Simulation in Healthcare, 6(3), 143-149.

Simpson, K. R., James, D. C., \& Knox, G. E. (2006). Nursephysician communication during labor and birth: Implications for patient safety. Journal of Obstetric, Gynecologic, and Neonatal Nursing, 35(4), 547-556.

Simpson, K. R., \& Knox, G. E. (2003). Adverse perinatal outcomes. Recognizing, understanding \& preventing common accidents. Association of Women's Health, Obstetric and Neonatal Nurses, 7(3), 224-235. 
Simpson, K. R., \& Lyndon, A. (2009). Clinical disagreements during labor and birth: How does real life compare to best practice? The American Journal of Maternal-Child Nursing, 34(1), 31-39.

Sinivaara, M., Suominen, T., Routasalo, P., \& Hupli, M. (2004). How delivery ward staff exercise power over women in communication. Journal of Advanced Nursing, 46(1), $33-41$.

Swinglehurst, D., Greenhalgh, T., Myall, M., \& Russell, J. (2010). Ethnographic study of ICT-supported collaborative work routines in general practice. BMC Health Services Research, 10, 348.

Van der Velden, J. (2009). Een goed begin. Veilige zorg rond zwangerschap en geboorte [A good start. Safe care in pregnancy and birth]. Utrecht, The Netherlands: Steering Committee on Pregnancy and Birth.

Van Kelst, L., Spitz, B., Sermeus, W., \& Thomson, A. M. (2013). A hermeneutic phenomenological study of Belgian midwives' views on ideal and actual maternity care. Midwifery, 29(1), e9-e17.

Wheatley, R. R., Kelley, M. A., Peacock, N., \& Delgado, J. (2008). Women's narratives on quality in prenatal care: A multicultural perspective. Qualitative Health Research, 18(11), 1586-1598.

World Health Organization \& United Nations Children's Fund. (2009). Baby-friendly hospital initiative: Revised, updated and expanded for integrated care. Geneva, Switzerland. Retrieved from www.who.int/nutrition/ publications/infantfeeding/bfhi_trainingcourse/en

Williams, K., Lago, L., Lainchbury, A., \& Eagar, K. (2010). Mothers' views of caseload midwifery and the value of continuity of care at an Australian regional hospital. Midwifery, 26(6), 615-621.

Acknowledgments. We thank Bart Penders, PhD, (Department of Health, Ethics \& Society, Maastricht University, Maastricht, The Netherlands) for his contributions to the study.

Funding was received from Zuyd University, Maastricht, The Netherlands \& CAPHRI School for Public Health and Primary Care, Maastricht University, Maastricht, The Netherlands. All authors have contributed significantly to the writing and the conception or interpretation of the manuscript and have consented to having their names mentioned on the manuscript. All authors have approved the final version of the manuscript and declare that they have no conflict of interest.

Correspondence regarding this article should be directed to Isabel van Helmond MSc, Zuyd University, Research Centre for Midwifery Science, Faculty of Midwifery Education \& Studies, P.O. Box 1256, 6201 BG Maastricht, the Netherlands. E-mail: I.van.helmond@av-m.nl

Isabel van Helmond, MSc, Research Centre for Midwifery Science, Faculty of Midwifery Education \& Studies, Zuyd University, Maastricht, the Netherlands.

Irene Korstjens, PhD, Research Centre for Midwifery Science, Faculty of Midwifery Education \& Studies, Zuyd University, Maastricht, the Netherlands.

Jessica Mesman, PhD, Department of Technology and Society Studies, Maastricht University, Maastricht, the Netherlands.

Marianne Nieuwenhuijze, RM, MPH, PhD, Research Centre for Midwifery Science, Faculty of Midwifery Education \& Studies, Zuyd University, Maastricht, the Netherlands.

Klasien Horstman, PhD, Professor, Department of Health Ethics Society, Maastricht University, Maastricht, the Netherlands.

Hubertina Scheepers, MD, PhD, Department of Obstetrics, Maastricht University Medical Centre, Maastricht, the Netherlands.

Marc Spaanderman, MD, PhD, Professor, Department of Obstetrics, Maastricht University Medical Centre, Maastricht, the Netherlands.

Judit Keulen, RM, MSc, Midwifery Practice Schoffelen, Maastricht, the Netherlands.

Raymond de Vries, PhD, Professor, Research Centre for Midwifery Science, Faculty of Midwifery Education \& Studies, Zuyd University, Maastricht, the Netherlands/ CAPHRI School for Public Health and Primary Care, Maastricht University, Maastricht, the Netherlands. 